\title{
Entrepreneurship and economic development in cities
}

Article

Accepted Version

Audretsch, D. B., Belitski, M. and Desai, S. (2015)

Entrepreneurship and economic development in cities. Annals of Regional Sciences, 55 (1). pp. 33-60. ISSN 1432-0592 doi: https://doi.org/10.1007/s00168-015-0685-x Available at https://centaur.reading.ac.uk/43286/

It is advisable to refer to the publisher's version if you intend to cite from the work. See Guidance on citing.

To link to this article DOI: http://dx.doi.org/10.1007/s00168-015-0685-x

Publisher: Springer

All outputs in CentAUR are protected by Intellectual Property Rights law, including copyright law. Copyright and IPR is retained by the creators or other copyright holders. Terms and conditions for use of this material are defined in the End User Agreement.

\section{www.reading.ac.uk/centaur}

\section{CentAUR}

Central Archive at the University of Reading

Reading's research outputs online 


\title{
Urban Entrepreneurship and Economic Development
}

\author{
David B. Audretsch \\ Indiana University \\ 1315 E. $10^{\text {th }}$ Street, Bloomington, IN 47405, USA \\ Phone: $+(812) 8556766$ Fax: $+(812) 8558014$ \\ E-mail: daudrets@indiana.edu \\ Maksim Belitski* \\ Henley Business School University of Reading, \\ Whiteknights, Reading, RG6 6UD, UK \\ Phone: +44 1183786231 \\ E-mail: m.belitski@ reading.ac.uk \\ Sameeksha Desai \\ Indiana University \\ 1315 E. $10^{\text {th }}$ Street, Bloomington, IN 47405, USA \\ Phone: +(812)8556766 Fax: +(812)8558014 \\ E-mail: desai@indiana.edu
}

\begin{abstract}
Policymakers have identified the relationship between entrepreneurship and economic development. Yet little is known about how this relationship varies over time in cities with different market size. This study examines the link between new firm start-ups and economic development using a panel of 127 European cities between 1994 and 2009. We found that the immediate economic development impact of new-firm start-ups is positive for both large and small and medium-size cities. The relationship is U-shaped for large cities, with the indirect effect taking 7 years. Indirect effect does not occur in small and medium cities supporting regional economy argument of agglomeration economies and a critical mass for growth. We offer useful information for policymakers, practitioners and scholars.
\end{abstract}

Keywords: entrepreneurship, economic development, city, Europe, agglomeration

JEL Codes: L26 M13 O18 R11 R50

*corresponding author 


\section{INTRODUCTION}

Entrepreneurship is widely seen as an important driver of economic development, employment and innovation (Chinitz 1961; Saxenian 1994; Rodriguez-Pose and Crescenzi 2008; Andersson and Koster 2011). The links between entrepreneurship and jobs, incomes, employment and population have shown to play a role in shaping economic policies affecting both urban and rural areas. These links are informed by a large regional economics literature that addresses both the determinants and outcomes of entrepreneurship at different levels of analysis (Audretsch 2003; De Groot et. al 2009; Acs et al. 2009; Glaeser et al. 2010, 2014; Andersson et al. 2011; Stam 2014;). Along with entrepreneurial activity that represents actions by individuals, the local context (Acs et. al. 2014; Stam, 2014) and specialization externalities, which operate mainly within a specific industry and geography (Marshall 1890; Jacobs 1969) affect the quality of economic development and value creation A local context includes formal institutions, entrepreneurship culture, infrastructure, demand but also human capital, networks, talent, new knowledge (Szerb et. al. 2013). Following a comeback of interest in local context and externalities over the last two decade, a number of new studies have appeared addressing various aspects of the relationships between entrepreneurship and economic performance in cities (Glaeser et. al. 2014). In this paper we focus on the role played by entrepreneurs in driving economic performance in cities of various sizes. In particular we examine the role played by new firm start-ups in driving economic performance in the context of European Union (EU) cities, and we explore key policies for cities of different size. We focus on European cities because many of the analytical frameworks and research over the last two decades and assumptions for regional and entrepreneurship policy have been shaped on the basis of either the North American or emerging country contexts (Porter 1990; Glaeser, Kallal, Scheinkman Shleifer 1992; Glaeser et. al. 2010, 2014; Florida, 2002; Florida et. al., 2008; Andersson et al. 2011), with a limited applicability and relevance to the contemporary European urban context (Capello et. al., 2008; Dijkstra, Garcilazo and McCann 2013). Limited evidence for European cities poses significant challenges for European regional policy-makers who need to recognise, assimilate but also ransform and exploit results for North American and developing countries to an EU policy-context. In particular the limited evidence makes it challenging to measure the role that entrepreneurs play in the economic performance, as entrepreneurial culture, local context for entrepreneurs and the ecosystem where entrepreneurs start business and survive various greatly among countries (Acs et. al., 2014). For a more complete understanding of how new start-ups contribute to economic development in European cities, it is important to recognize the contextually embedded entrepreneurial action (Szerb et al. 2013)and the way knowledge diffuses (Acs et. al. 2009) . 
The main contribution of this study is in investigation the lag structure of the effect of new firm start-ups on urban economic development in small and medium-size vs. large European cities. Rather than dividing the sample by cities with various population density that demonstrates availability of social and business networks and agglomeration effects (Glaeser et. al., 2010; De Groot et. al. 2009; Leyden, Link and Siegel, 2014) we validate and quantify the direct and indirect effects of start-up on urban performance by the market size e.g. the number of residents using the Eurostat and OECD methodology (Dijkstra, Garcilazo and McCann 2013). Direct effect of start-up is the initial employment (value added) created in the newly founded businesses, while indirect effect is the employment (value added) gain due to indirect supply-side effects such as securing efficiency, amplified innovation, greater variety, improved competitiveness. Indirect or also known as spillover effect on employment in large cities is the result of relatively higher degree of competition in these areas, which results in creative destruction (Schumpeter 1934, 1949).

We use GDP per capita in purchasing power parity capturing the value added of entrepreneurship, and not the population or employment growth which captures rather a number of job creation and number of people moved in a city (Audretsch, 2007; Cheshire and Magrini, 2009; Glaeser et. al., 2010). Thus, this study captures real changes in the economic value of new firm startup in European cities over 1994-2009 years. It covers richer local contexts than in the case of empirical studies for specific countries e.g. Germany (Audretsch and Fritsch, 2002), Netherlands (Stam, 2014), USA (Crescenzi et al 2007; Glaeser et. al., 2010, 2014), other European countries (Bosma et. al., 2012).

We focus on a city-level for three main reasons highlighted in a leading literature owith one or two country studies. The results and interpretations clearly suggest that the analysis of the value added of new start-ups that mainly focuses on the development of entrants is inadequate in large-size cities due exiting capacity effects (Fritsch and Mueller, 2004), but could be an efficient policy in small cities. In addition, the indirect supply-side effect of entries only occurs in large size cities, needing critical mass. As in the basic model illustrates, whether on the side of the newcomers or on, the start-ups exhibit the strongest the indirect effect in large size cities after six years due to spillover effects later on to incumbents.

Our main finding is is that the effects of new business formation on economic development emerge over a relatively long period of time. Adding to the knowledge of a 'wave' pattern of employment growth in various agglomeration economies (Fritsch and Mueller, 2004), the impact of new firm start-ups on economic value generated in a city repeats a "wave" effect. This wave effect includes both direct and indirect effect of new start-ups on economic development and suggests different phases of new firm impact that can take up to seven years to be fully exploited. 
This study argues that the indirect effects on incumbents tend to be considerably more pronounced than the direct effects, and could be explained by differences in a city size(Beaudry and Schiffauerova 2009). We explain this by a critical mass accumulated in large cities needed to spill over ideas and generating more growth(Acs et al. 2009).

To test our hypothesis on the lag impact of new firm start-ups on urban economic development in small and medium-size vs. large European agglomeration economies (Beaudry and Schiffauerova 2009) (test we utilise European Urban Audit data during 1994-2009 which includes 127 European cities at the different level of economic and business development in East and West Europe.

Our work contributes to regional economies and entrepreneurship literature in three important ways. Firstly, we decompose the overall growth effect of new business formation into the newcomers effect (the direct effect) and the (indirect) effect on the employment in incumbents across cities of various market sizes. Time dimension allowed us to investigate this over time (e.g. van Stel and Suddle 2008; Brakman et al. 2009).

Secondly, we examine both direct and indirect effects of new firm entry on economic performance in cities drawing on a market size rather than population density as previous studies (Glaeser, Kallal, Scheinkman and Shleifer 1992; Saxenian 1994; De Groot et. al. 2009.

Third, our analysis enables better design of regional policy by promoting higher new firm startup rates in large cities. Given large agglomeration externalities (Jacobs, 1969; Rosenthal and Strange 2003; Beaudry and Schiffauerova 2009) an indirect spillover effect of new business formation increases significantly compared to the initial direct effect. The relationship is U-shaped in large market size cities where both displacement and spillover are present. Small and medium size cities with less than 250,000 inhabitants need larger markets to experience the spillover effect.

The paper is structured as follows. In the next section, we will review relevant theories which provide insight into the relationship between entrepreneurship and economic development in cities. In the third section, we will present our econometric model, data, variables used in the study, estimation procedure and measures. We will present our results in the fourth section and perform a robustness check on estimation in section 5. We provide a discussion on policy implications in in the sixth section, followed by a conclusion.

\section{LITERATURE REVIEW}

\section{Entrepreneurship and growth theories}

Cities as broadly integrated economic units have witnessed a revival of interest in the role they play in regional and national economies (Glaeser et al. 1995; Acs and Armington 2004; Glaeser and 
Kerr 2009; Stam 2014) and regions (Bosma and Sternberg 2014; Fritsch and Storey 2014). It has also become common practice to analyse the effects of new business formation on economic performance at a regional level, because an analysis of these effects at the industry level causes serious difficulty in interpretation (Klepper 1997; Fritsch and Noseleit 2013). Using new metrics for cities from the Global Entrepreneurship Monitor (GEM) which includes data from 47 urban areas in 22 EU countries, Bosma and Sternberg (2014) ask a rhetorical question: is entrepreneurship an urban event? This study is another Lucas's (1988) test of the greater role of cities as clusters of human capital and skilled-workers. Larger, more diverse metropolitan areas increase the size of the local labour force, reduce the cost of information flows, create knowledge spillovers and support the growth (Feldman 2001) of the "Marshall-Arrow-Romer" externalities" (Marshall 1890; Glaeser et al. 1995; Crescezi et al. 2007; Szerb et al. 2013).

Although the historical evidence of entrepreneurship-led growth in cities is vast (Beaudry and Schiffauerova, 2009; de Groot, Poot and Smit 2009; Rosenthal and Strange, 2004)) to name a few, the contexts that transforms new business into economic development and the mechanisms applied remain under researched (Beaudry and Schiffauerova, 2009) ). In this study urban entrepreneurship is not seen as exogenous, but a purposeful activity demanding real resources, including time (Audretsch 1995).

Regional economics and entrepreneurship literature focuses on the dynamics of entrepreneurship (Glaeser et al. 2014a; Fritsch and Wyrwich 2014a) with time as an important dimension of growth (Audretsch and Fritsch 2002). Previous research from the traditions of growth economics (Barro and Sala-i-Martin 1991) and regional economics (Glaeser, Kallal, Scheinkman and Shleifer 1992, 1995; Florida 2002; Florida et al. 2008; Acs et al. 2009) lays out a strong role for the entrepreneur as an endogenous source of economic development. Entrepreneurship is often seen within regions as a conduit for creativity and technology (Florida et al. 2008; Audretsch and Belitski 2013), human capital and knowledge spillovers (Crescenzi et al. 2007; Faggian and McCann 2009). Along with human capital, skills, technology and creativity; externalities, such as scale economies were found to be positively associated with regional productivity (Marshall 1890; Chinitz 1961; Saxenian 1994).

For this reason, agglomeration in cities goes beyond simply the establishment of an industry base, but also supports labour market expansion, firm specialization within industries, and engagement with customers and suppliers (De Groot et. al. 2009). Agglomeration economies essentially provide a larger market, which can increase the returns to business entry. As Reynolds et al (1994) point out population growth and high population density undoubtedly affect the number of entrepreneurs and regional development. The recent research demonstrated that entrepreneurs favour 
larger market potential (Glaeser et al 2010). Large markets allow firms to benefit from economies of scale and generate externalities (Jacobs 1969; Ac et al 2009) providing further incentives to entrepreneurship, innovation and growth (Acs et al. 2008a).

Disentangling the impact of entrepreneurship on economic performance in cities is a difficult task for two reasons: we need a sufficient amount of time serious data and lags (Fritsch and Mueller, 2008); we need a robust indicator of value added and economic performance. Although regional economics scholars use population change, employment growth population growth and income (Fritsch and Mueller 2004, 2008; Mueller et al. 2008; Glaeser et al. 2010) as a measure of economic development, GDP per capita in PPP is a preferred measurement Given a high job market mobility in Europe (Stam 2014) the measurement of economic development by a number of full-time job placements is not appropriate. Job unit does not equalise to income and productivity growth. Moreover it does not capture heterogeneity of a labour force and its results . On the contrary, GDP does capture labour efficiency challenged by technology, inter-regional and inter-national knowledge flow, outsourcing. Although it does not differentiates between resource-based and knowledge-intense businesses, it measures how much value was added in a city by employees. The existing theoretical and empirical literature thus indicates the need to focus specifically on measuring changes in economic development in cities overtime.

\section{New business entry and economic development phases}

Previous studies on the relationship between the dynamics of economic development and new firm start-ups phases accounted for only relatively short time-lags and had mixed results (Carree and Thurik, 2008, 2010; Fritsch 2011). Theories linking time factors to new business entry and growth suggested the effect of new business formation on economic development is influenced by three types of effects: the direct effect on growth and job creation, the displacement effect and the spillover effect or the supply-side effect (Audretsch and Fritsch 2002; Fritsch and Mueller 2008). Figure 1 in Appendix illustrates these three stages of new entry effect on growth overtime. In short, the empirical evidence suggests that the impact of new firm formation on employment growth, population growth and enterprise growth in a region is automatic and positive ${ }^{1}$.

Later Mueller et al. (2008) as an empirical suggestion using smoothened lag structure suggested that new business formation has a positive impact on employment change in the year of foundation and then until $t+5$, the effect is negative, with a minimum in $t+3$. The instant positive effect of new firm formation on employment enters in the second "displacement phase" when incumbent companies are replaced by more efficient new start-ups and positive effect of the entry fades away. The effects gets beck to positive in years $t+6$ to $t+9$ with a maximum between years $t+7$ 
and $t+8$. The magnitude of the effect then decreases and becomes statistically insignificant with time. The importance of the indirect spillover effect for economic development is vast and in a large part is driven by the business climate and agglomeration economies which enable further positive effect on growth (Mueller et al. 2008). Theoretical and empirical studies have provided robust evidence suggesting the dominating role of agglomeration economies driving the indirect spillover effect which could indeed be critical to growth (Saxenian 1994; van Stel et al. 2005; van Stel and Suddle 2008Glaeser et al. 2014b). Amongst those we assume accelerated structural change by means of increased turnover of economic units due to market selection; innovation processes, particularly the creation of new markets, and greater variety of products and problem solutions that, in turn, may have the potential to create new economic opportunities (Fritsch and Mueller 2004; Fritsch and Noseleit 2013). , In addition, such factors as knowledge spillovers, labour markets and rates of innovation (Glaeser et al. 1995, 2010) University-private partnerships can be an important anchor tenants for regional growth (Hausman 2012).

This type of lag structure of the effects of new business formation on economic performance of regions is confirmed in a number of empirical analyses after Fritsch and Mueller early 2000s studies (Andersson and Noseleit 2011; Baptista and Preto 2011; Carree and Thurik 2008; Dejardin 2011).

Although above studies confirm the initial positive effects of new business formation, its strengths and idiosyncrasies across large and small cities may skew the findings (van Stel et al. 2005; Fritsch and Storey 2014; Fritsch and Wyrwich 2014a, b).

This study poses a question: does the indirect effect happen in small cities with a limited market size? According to Fritsch and Mueller (2004, 2008), a main reason for the positive longterm indirect effect on employment effect of start-ups in agglomeration economies is the relatively high degree of competition in these areas, which results in creative destruction (Schumpeter 1934, 1949;) and survival-of-the-fittest company in the market that creates a greater variety of products, offer better technology and cost-efficient problem solutions that, in turn, may have the potential to create new products and markets and destroy out-dated technology. A relatively high competition is a direct result of the higher market size in a city. Hence more firms demanding similar inputs or supplying goods and services to the same market (Fritsch and Mueller 2008).

In cities with a small market size, the indirect effect may not occur because of lower externalities and a lack of critical mass to compete, creative destruct incumbents (Schumpater 1939; Jacobs 1969). A lack of agglomeration externalities reduces competition and knowledge flow making indirect effect subtle.

Based on a trade-off between market size advantages and disadvantages (Brakman et al. 2009), the spillover effect will appear in cities with larger markets, so increasing the disproportionate 
amount of entrepreneurship (Andersson and Koster, 2011) and enforcing creative destruction (Schumpeter, 1934, 1949; Andersson et al. 2011) we expect:

H1: New business formation makes a significant positive impact on urban economic performance independently of its market size.

$\mathrm{H} 2$ : The indirect effects of new business formation on economic performance are responsible for the U-shaped pattern in cities with large market size.

$\mathrm{H} 3$ : The indirect effects of new business formation on economic performance do not mature in cities with small and medium market size.

\section{EMPIRICAL MODEL AND DATA}

\subsection{Urban entrepreneurship and importance of cities}

In this study we focus on testing the economic development impact of new-firm start-ups in European cities, comparing and contrasting between large cities on one side (> 250K residents) and small amd medium cities on the other ( $<250 \mathrm{~K}$ residents).

Following economic geography scholars (Porter 1990; Glaeser et al., 2014; Fritsch and Storey, 2014; Camagni et al. 2015) the early 1990s and 2000s witnessed a revival of interest in the role played by cities in regional and national economic performance. There are at least three reasons provided in a leading literature (Dijkstra, Garcilazo and McCann 2013; Bosma and Sternberg, 2014;). First, in Europe unlike the rest of the world (e.g. North America, South America, South-East Asia or Russia), diversity of local context (Szerb et. al., 2013) is mixed with unification and integration of institutions, entrepreneurial cultures and high urbanisation rates. High differences between East and West Europe are interesting to investigate at a city-level along with the cluster development, emphasizing the importance of city focus (Fritsch and Storey, 2014). Second, entrepreneurial ecosystems are seen as a localized 'container', enabling primarily local interactions (Stam, 2014), Third, as a practical issue, the Eurostat collects harmonized and synchronised data across EU regional and urban economies with a higher degree of reliability and control over harmonization . This enabled secured data and reliable comparisons and contrast between cities with different local context but all located within the European Union. A good example of such new data is the European Urban audit project which also runs in all Eu-member states (Eurostat, 2011).

Cities are broadly integrated economic areas and more suitable units for analysis than countries or regions (Chinitz, 1961; Armington and Acs, 2002; Glaeser et al., 2001, 2010; Bosma and Sternberg, 2014). Our local unit of analysis is a city. City is described here as the Functional Urban 
Area (formerly known as larger urban zone LUZ), which consists of a core city and its commuting zone. A core city is a local administrative unit (LAU) where the majority of the population lives in an urban centre of at least 50,000 inhabitants (Eurostat, 2011). The "core city" definition used in the Urban Audit corresponds to the "administrative city" with political responsibility (usually the municipality or equivalent) in all cases, with exception of Brussels and Cyprus.

OECD developed a new definition of a city in 2012 (OECD, 2012). This new OECD-EC definition identified 828 (greater) cities with an urban centre of at least 50,000 inhabitants in the EU, Switzerland, Croatia, Iceland and Norway. This Regional Focus describes on the European cities: a new way to measure metropolitan areas (OECD 2012; Dijkstra and Poelman, 2012). Half of these European cities are relatively small with a centre between 50000 and 100000 inhabitants. According to OECD small-sized cities are between 50-100K inhabitants, medium-sized cities - 100-250K inhabitants, and large-sized cities , also known as metro areas (Eurostat, 2011) a greater than 250K inhabitants. Given the change in the definition took place in 2012 while our data is before 2012, according to Eurostat (2011) we place medium-sized cities within the population less than $250 \mathrm{~K}$ inhabitants acknowledging the OECD recent change.

\subsection{Sample and data description}

To investigate the economic development impact of new-firm start-ups, we use a fairly new database made available by Eurostat and the Urban Audit Project. The European Urban Audit Survey $^{2}$ (UAS) was constructed by Eurostat from its national statistics on cities, regions and businesses (developed from annual files on cities and large urban areas for the intervals of 4 to 5 years beginning in 1993). The Urban Audit identifies a spatial unit as a core city if it has at least 50,000 inhabitants. In this study we distinguish between a metro region - represents a metropolitan area with at least 250,000 inhabitants (large cities) and medium and small-sized cities with less than 250,000 inhabitants. These areas were identified based on the Larger Urban Zones as used in the Urban Audit. These contain a major city and their surrounding travel-to-work areas. They consist of administrative areas (Eurostat 2011; Dijkstra, Garcilazo and McCann 2013). We utilise the data on Urban Audit project and Eurostat has been responsible for coordinating the flow of Urban Audit data at the European level (Eurostat, 2011). We use a sample of 127 European cities (both metro and nonmetro regions) between 1994 and 2009. The cities in our sample are located across 11 Western European and 7 Eastern European countries (see Figure 2 and 3 in the Appendix). Selection of participating cities and the definition of the composition of the LUZ and the SCD in terms of spatial units had to meet certain criteria: the participating cities in each country should represent about $20 \%$ of the population in that country; the participating cities should reflect a good geographic distribution 
within the country (peripheral, central), coverage should reflect a sufficient number of medium-sized cities (medium-sized cities having a population of 100000 - 250000 inhabitants, large cities with $>250$ 000), data should be available and comparable; where possible regional capitals ${ }^{3}$ were included; both large and small cities were included; cities were geographically dispersed within each member state. 322 cities in 27 Member States participated in the survey, plus 47 cities from Switzerland, Norway, Croatia and Turkey.

In 1999 the Commission conducted a tentative data collection over the period 1994-1999 of comparable indicators for 58 European cities. The purpose of this first "Urban Audit" was to test the feasibility of collecting comparable measurements of the quality of life in European cities. Over the entire EU (EU- 15 at the time), around 480 variables were collected for the 58 largest cities. Therefore, we have only 58 largest cities we were able to include in the sample from the very first period. After completion of the Urban Audit, the Commission decided that there was a clear need to continue and improve this approach of collecting comparable information on urban development. The next data collection waves for Urban Audit data took place in 2003 (for EU-15 cities only) respectively 2004 (for the new Member States) and in 2006/2007 (for the EU-27 cities plus cities in Norway, Switzerland, Turkey and Croatia). We acknowledge a limitation of data as only 127 cities were made available for the model of interest, having 127 cities in our sample both in EU15 and New member states is a good result given the number of cities and variables available has increased overtime from 58 cities in 1999 to 322 cities in 2011. Although our sample cannot capture all 322 cities overtime, following the data collection criteria above used by Eurostat and having almost equal number of cities from west and east European countries of various sizes enables us to say that the data is representative for European cities.

\subsection{Dependent variable}

For the EU cities triannual economic performance GDP per capita in purchasing power parity was used as a dependent variable. Economic performance is measured as a logarithm of GDP per capita in purchasing power parity prices (PPP), in Euro (Eurostat, 2011). GDP per capita was used in the extant literature as an indicator for economic wealth and growth at both the regional and country levels (e.g., Anselin 2010; Glaeser et al. 2010; Stam, 2014). It was also used as a robust variable for regional value added and economic efficiency in the analysis of urban vs. rural regions performance (Dijkstra, Garcilazo and McCann 2013). In this sense, GDP per capita as opposed to income (Florida et al. 2008) and employment growth (Baptista and Preto 2011; Fritsch and Noseleit 2013) has two main advantages: it is place-dependent and it demonstrates value added as a measure of economic 
efficiency and financial viability of a city, rather than a number of job creation. Given the increased job market mobility in Europe (Stam 2014) the measurement of economic development by a number of full-time job placements is limited. In addition employment growth is unable to capture labour productivity.

We are aware that the GDP level could be overestimated in cities, where administrative boundaries exclude significant dormitory areas (suburbs) (Cheshire and Magrini 2009) which is not the case of our sample (Eurostat, 2011). Definitions and sources of all our variables are listed in Table 1. Correlations reported in Table 2.

- TABLE 1 and 2 -

\subsection{Empirical model and explanatory variables}

Our key explanatory variable is entrepreneurial activity, measured as a number of firm startups (Armington and Acs, 2002; Audretsch et. al., 2006), i.e. number of births of enterprises in each of triannual period taken in logs. A number of studies stress how important new firm formation is for economic development and providing commercialisation and access to ideas and the recognition of opportunities (Shane and Venkataraman 2000). Our main variable of interest is executed at a city level. The choice of entrepreneurial activity proxy is triggered by exhaustive economic geography literature linking economic development (Capello et. al., 2008; Acs et. al., 2009; Dijkstra, Garcilazo and McCann 2013) to entrepreneurial activity often described as entrepreneurial events (Shane and Venkataraman, 2000; Audretsch, 2007; Zahra and Wright, 2011).

New businesses registered in a given region defined by a number of births of enterprises registered to the population concerned in the business register corrected for errors. Our data includes new businesses which have both fewer and more than 10 employees $^{4}$. Figure 2 in the Appendix shows the average new firm start-ups rates between 1994 and 2009.

\subsection{Control variables}

As a first control variable we use an unemployment rate in a city, in particular we included a unemployed in year in a total number of residents in the working age. Conflicting hypotheses are posited in the economic literature in regard to the impact of unemployment on regional growth. Higher unemployment indicates lower resilience and lower number of capabilities, but also higher labour reserve and market mobility (Stem, 2014). We expact statistically significant and negative relationship between unemployment rate and economic development (Fagerberg et al. 1997)

Previous research suggest including either employment rate (number of residents that are employed) or an unemployment rate as a control variable for economic performance(Fritsch and 
Storey 2014; Fritsch and Wyrwich 2014b). Due to multicollinearity between these two variables we chose to drop employment and use unemployment rate as a control for urban economic performance (see Table 2)..

Our second control variable is human capital ( Glaeser, Kallal, Scheinkman and Shleifer 1992). A wide range of empirical studies have documented the role of human capital in regional growth (Chinitz 1961). Human capital is measured as the proportion of residents with a "high" (university and college degree) and "medium" (high school degree) level of education. Higher level of human capital is associated with higher economic growth and development (Glaeser, Kallal, Scheinkman Shleifer 1992; Audretsch 1995; Rodriguez-Pose and Crescenzi 2008)

Our third control variable is the World Economic Forum Global Competitiveness Index, known as GCI (Department of Trade and Industry, 1998; Aiginger, 2006). GCI is measured at the country level, however it is a robust proxy for the level and quality of national institutions as well as the level of competition, networks, entrepreneurship culture, infrastructure, stability, labour and capital markets, technological advancement and other dimensions related to overall economic development (Aiginger, 2006; Schwab 2010). Although GDI per se does not capture the variation between cities within one country it does at country-level for the differences in national institutions, the speed of economic reforms and business environment. Above indicators are relevant for shaping the business environment for economic growth (Schwab 2010; Glaeser et al. 2014; Estrin et al. 2013). We have grouped countries into three controls based on their competitiveness ranking: high (the top twenty most competitive countries), medium (the next fifty countries) and Low (the remaining countries). Countries with a high level of GCI has strong positive and significant correlation with the GDP per capita in a city 0.67 (Table 2), while low GCI has negative and significant correlation with the GDP per capita in a city -0.52 (Table 2). We therefore expecting higher GCI index of the country will be associated with a higher level of economic development in cities within this country.

Our fourth set of control variable is city-type dummies. Although the panel element is low (on average we have 2.4 observations per city) we control for a city fixed effects and therefore for unobserved heterogeneity. We are aware by including 126 (127-1) dummy variables associated with each city we would be exploiting our degrees of freedom in a sample of 319 observations. This may potentially decrease the quality of estimation. As a set of control variables we introduce a set of citytype dummies where one or zero is associated with a specific city type taken from European Commission, State of European cities report (2007). We find applying city-type fixed effect is more beneficial than traditional city-fixed effects. We include 13 city-type dummies Knowledge hub, Deindustrialised cities, Gateways, Regional market centres, Research centres, Modern industrial 
centres, Re-invented capitals, Regional public service centres, Satellite towns, Visitor centres, Established capitals, National service hubs, Transformation poles in our model described in State European cities report (2007). In addition to city-type fixed effects each city type is associated with a specific industry structure, population growth, density, city size, location and functionality. Allocation of cities to each type class was done based on the European State of Cities report 2007.

For instance, research center dummies follow the rich literature that examines the role of universities and research institutions related to economic development as they play a key role in producing creative and human capital (Florida et al. 2008). Research centres and knowledge hub cities rely on higher world integration in knowledge finance and universities are expected to be positively associated with economic development and have on average higher economic growth (Saxenian 1994; Audretsch 2003; Acs et al. 2009). Other studies also argued that universities serve as a spillover of human capital in cities (Faggian and McCann 2009; Belitski and Korosteleva 2011).

Our fifth control variable is industrial diversity of a city. In terms of potential impact on economic development, it is unreasonable to expect that labour and knowledge-intensive industries will have the same effect on economic growth. Industrial diversity in a city is controlled by including the number of employed people in the industry per 1000 residents $^{6}$, in five broad industries which were included in the model groups. These were agriculture and fishery; trade hotels and restaurants; mining, manufacturing and energy; financial intermediation and business activities; public administration, health and education following $\mathrm{NACE}^{7}$ classification of industry sectors. Mining, manufacturing and energy, financial intermediation and business activities, public administration, and health and education altogether account for approximately $70-80 \%$ of all workers on average across the European cities between 1994 and 2009.

The coefficients will account for the average impact of each industry on the average change in the GDP per capita. As all industries have the same measurement - a number of employed people in the industry per 1000 residents, the difference in the coefficients will explain the relative impact of each industry on our dependent variables as opposed to the reference industry.

As a sixth control variable we include EU dummy for cities that are located in East Europe vs. West Europe. This is to capture potential effect of post-communist world culture and the differences in the level of economic development, institutions between cities in the East and West Europe (Estrin et. al., 2013).

Finally we include time dummies to control for the effects that have not changed across cities but have changed overtime in our mixed model (Baltagi 2008) for each time period. The time periods were chosen as to a starting in the first year of each period ${ }^{8}: 1994 ; 2000,2003,2005$ and 2007. Period 2007-2009 with the year 2007 is a reference category. 


\subsection{Econometric model.}

We estimate a Random effect panel data model with each city having at least two observations over the period 1994-2009. We control for city-specific characteristics by including city-type fixed effects. We also control for time fixed effects by including time period dummies in the regression. Ftest for the joint significance of city-type effects and time controls were implemented. We consider the following linear panel regression model which resembles Cobb-Douglas production function at a regional level (Douglas 1976):

$$
Y_{i t}=\alpha_{i}+d_{t}+\beta_{1 i} x_{i t}+\beta_{2 i} \dot{x}_{i t}+\mu_{i t}
$$

where $i=1, \ldots, \mathrm{N} ; t=1, \ldots, \mathrm{T}$; where $Y_{i t}$ indicates GDP per capita in PPP of a city $i$ at time $t$, $x_{i t}$ is a $k \times 1$ set of regressors including entrepreneurship variable along with other control variables (e.g. high and medium education, sector specialization, high/medium/low competitiveness, EU joining dummy, city type); $\dot{x}_{i t}$ is a $k \times 1$ set of potential endogenous variable unemployment rate; $\alpha_{i}$ is a city- specific intercept, $d_{t}$ is time control, and $\mu_{i t}$ is the two-component error term. All variables in (1) are expressed in logarithms except for those expressed in percentages. The model assumes one-way error component model for disturbances, with

$$
\mu_{i t}=\gamma_{i}+\varepsilon_{i t}
$$

where $\gamma_{i}$ is the $m \times 1$ vector of the unobservable city fixed effect and $\varepsilon_{i t}$ is a city-specific error assumed to be independent and independently distributed. From (2), the issue of correlation arises because responses to shared external shocks could be similar, though not identical, across cities. In model (1), we assume the $x_{i t}$ and $\dot{x}_{i t}$ are independent of the $\varepsilon_{i t}$. Heterogeneity across the cities is captured by the city specific intercept, $\alpha_{i}$, the time dummies, $d_{t}$.

The unobservable city-specific effects $\gamma_{i}$ are assumed to be random parameters, and the remaining disturbances stochastic with $\varepsilon_{i t}$, independent and identically distributed (Baltagi 2008).

We first estimated a model using the proportion of new business registered contemporaneously with the GDP per capita in PPP. We then estimated a model using the first lag of new business entry rates (3-7 years before the impact) and the second lag (8-11 years before the impact). We split the sample between small and large cities testing Lucas's (1988) and Brakman's et al. (2009) argument. The results are reported in Table 3.

- TABLE 3 - 
There is a potential issue of a reverse causality between unemployment rate and the GDP per capita in PPP also known as the endogeneity problem. We use a first lagged level of the unemployment rate with each lag being four years in the past, as an Arellano-Bond type instrument to solve the endogeneity problem (Arellano and Bond, 1991). One lag equals to a four year period, which minimizes possible business cycle effects between unemployment and GDP per capita in PPP. Unemployment rate in the model (1) could be potentially correlated with the unobserved effects in the residual, making standard estimators inconsistent. Arellano and Bond (1991) type estimator derived a consistent generalized method of moments (GMM) estimator, by using a lagged variables with zero covariance between the explanatory variables and a residual. This means minimal likelihood of interdependence between the first lagged unemployment rate and any other effects in the residual that may affect GDP per capita. Thus, unemployment lagged is unlikely to be correlated with any effects in the residual which minimises the risk of endogeneity in a model. In addition we run Hausman test (Baltagi, 2008) which aims to test the covariance between the lagged unemployment rate and other explanatory variables in the model and unobserved effects in the residual. The difference between the current residual that affect GDP and lagged unemployment rate is four years. Hausman test comparing two cases within specification 1 Table 3 (small and medium cities) and two cases within specification 4 , Table 3 for large cities rejected the null on zero covariance between explanatory variables when unemployment was taken at its current level. Hausman test provided an empirical solution for endogeneity in a model by including lagged unemployment rate. 4. RESULTS

Our data on start-ups, GDP and other control variables including population, city types, human capital and others are derived from the establishment file of the Eurostat (2011) on 127 European cities over the period 1994 to 2009. We found strong evidence that entrepreneurial activity has a strong and immediate positive impact on economic development in cities with large, medium and small market sizes. The time effect is idiosyncratic for various agglomeration economies in both time and size aspects. Building on the previous studies (Fritsch and Mueller 2004, 2008) and van Stel and Suddle (2008) our first important finding is that the positive direct effect of new firm start-ups on economic performance is also validated for cities with various market size. This is in contrast to agglomeration economies effect described in Fritsch and Mueller $(2004,2008)$ relying on population density. Unlike in Fritsch and Noseleit (2013) we were able to confirm the positive effect for either market size city (Table 3, specifications 1-6). Our second finding is that the positive effect of new entries on economic development can be observed over the period of three years and then the effect disappears in large cities. This supports the displacement argument and creative destruction 
mechanisms in a large agglomeration economy with a particular focus on city size (Schumpeter 1934, 1949; van Stel et al. 2005; De Groot et. al. 2009; Andersson et al. 2011). A 10 percent increase in the proportion of new firm start-ups in small and medium size cities ( $<250,000$ population) is rewarded with an average of 4.1 to $4.8 \%$ economic development during the first seven years after the entry. The immediate economic development impact of new-firm start-ups (1-3 years) is higher than in the following period (4-7 year). This extends finding for German, Dutch and UK regions with the peak impact of new start-ups occurring within 5 years on employment growth, but now on economic value added as well. Interestingly, the direct effect has a different magnitude in smaller and larger markets as we can observe the displacement effect does not occur in smaller agglomerations, while it takes over in large market supporting hypothesis two (see specifications 4-6 Table 3).

negative growth between the years 4 and 7. It illustrates that incumbents shrunk in employment and growth and the displacement effect taking place (Fritsch and Mueller, 2004;; Van Stel and Suddle 2008). An increase of new firm start-ups by $10 \%$ is rewarded with on average $3.7 \%$ increase in economic development in the first stage (the direct effect) and 7.2\% increase in economic development on the third stage (the indirect effect). Our third important finding on the supply-side effect for large cities driven by productivity and knowledge spillover is greater than the direct effect of creating jobs. This has an important implication for regional economic policy. In particular it justifies public support to new business formation in large cities as the initial direct effect and creative destruction of incumbents (Schumpeter 1934, 1949) is offset by an increase in supply-side effects due spillovers in cities reaching its critical mass.

As expected no indirect effect of new business formation on economic performance in cities with small and medium market size cities, supporting our hypothesis three. As explained in the theoretical section, a main reason for the relatively weak long-term economic development effect of start-ups in cities with a small market size is the relatively lower degree of competition and lack of critical mass for the knowledge to spillover (Acs et. al. 2009). Small and medium size cities are not conducive to survival-of-the-fittest selection. Incumbents themselves are not challenged with available market niches. Another explanation could relatively limited technologies for companies that operate in smaller cities as opposed to start-ups in large market cities where the survival of the fittest is stronger and more advanced tech needed to survive and grow (Fritsch and Noseleit 2013).

The rest of the section will deal with the analysis of growth factors between small, medium and large cities.

First, we attempted to control for the differences in a labour market pool between large and small cites as well as between the lagging and wealthier cities. We used the level of unemployment for this purpose. We found statistically significant negative relationship between changes in 
unemployment rates and rates of economic development. An increase of $10 \%$ in the unemployment rate in large cities results in a decrease of GDP per capita growth on average between 0.26 and 0.62 percent. This finding marginally holds for small cities where changes in economic development are less sensitive to unemployment rates. Human capital proxied by the formal educational attainment (Glaeser et al. 1995; 2010) is found to have no effect on economic development in both small and large agglomeration economies (Rodriguez-Pose and Crescenzi 2008). Research and knowledge hub have positive effect on economic development in large agglomeration economies as opposed to small agglomerations. It is accepted that university is a necessary, but insufficient condition for attracting educated people to a region (Saxenian1994; Acs et al. 2009).

Established capital that are large agglomeration economies, experience on average $0.20-0.23 \%$ higher economic development rates than non-capital cities. Further findings support Lucas's (1988) and Brakman's et al. (2009) arguments about the clustering effect of human capital, which embodies the knowledge factor in agglomeration economies and results in higher information exchanges, larger labour markets, and greater knowledge spillovers that go on to become engines of economic development (Crescenzi et al. 2007; Glaeser et al. 2010; Audretsch 2003; Acs et al. 2009). Knowledge hubs and research cities in larger agglomeration economies have on average 0.2-0.3\% higher economic development than other city-types. We found a negative relationship between the proportion of adults with lower levels of education (ISCED 3-4 level or secondary education) defending the importance of human capital for economic development (Lucas 1988; Glaeser et al. 1995). This outcome highlights the important aspect of future research that links knowledge inputs to knowledge outputs at various levels of agglomeration (Audretsch 1995; De Groot et. al. 2009). Time dummies coefficients do not give reason to suspect a structural break in the data over time.

\section{Robustness check.}

One of the limitations of this study is the number of observation available and the number of explanatory variables in the model. The main point to be addressed here is the analysis has only 319 observations in total. Econometricians will argue on using a rule of thumb that requires at least 15 d.o.f. for every variable (Baltagi, 2008). Our Table 3 contains 17 variables including the dummies; and that is without taking into account that the lagged values of new firm formation (L.1 and L.2) make some of the sample disappear. We perform as robustness test of our model (1) estimation using only the major variables of interest linked to our hypothesis 1-3. We also include EU, human capital, unemployment rate controls as well as GCI Index dummies and industry shares at a city level. Number of observations in the original sample is 207 for large cities and 112 for small and medium cities. City type dummies, time dummies as well as city-type fixed effect were not included in this 
model attempting to achieve maximum degrees of freedom. F-test for all city dummies could not be performed as well. Rather than employing panel data estimation (mixed effects, random effects or fixed effects) we run simple OLS estimation pulling all periods into one cross section. Standard errors robust for heteroskedasticity with only 12 explanatory variables are included in both city-sizes in Table 4. We therefore had 189 d.o.f. for large cities, and 99 d.o.f. for small and medium-sized cities. Our results in Table 4 supported the final results in Table 3, although the pulled OLS makes the coefficient of interest upward bias on approximately 25 percent higher estimation coeffieicnts for small and medium sized cities and up to 30 percent upward bias for large cities. The significance of estimated coefficients of interest - new firm start-up rates have not been affected. Interestingly, the coefficients of other control variables, in particular unemployment, human capital and some industries turned to be statically significant.

We experimented whether our main research hypothesis hold by shifting the threshold of 250,000 inhabitants to 400,000 inhabitants for large cities and loosing almost a half of the large city sample which was originally 207 observations. The result although were less statistically significant for our hypothesis H1-H3 remained valid. Robustness check and experimenting with a small and medium size city sample was not possible due to number of observations. We run only basic model (1) with 12 explanatory variables while changing the threshold size from 250,000 to 400,000 inhabitants.

\section{Policy Implications}

Our study has the following limitations that need to be taken into account when interpreting the results and developing policy. Not all cities would be rewarded with more growth if more new firm formation takes place. Some cities may already have entrepreneurship levels above the optimal and the level remain sustainable overtime (Andersson and Koster 2011). Consequently, an increase in the rate of entry could lead either to creative destruction, or to an economic development penalty.

Market entry and market size are significant factors shaping city's economic development. The economic development plan for regions may want to support new business formation and the formation of "knowledge-based" cities.

Policies targeting the indirect spillover effect need to take into account the size of the agglomeration economies and the new firm start-up - growth effect over time. Smaller cities where the direct effect is more persistent, but the indirect supply-side effect does not occur, may still benefit from new business formation enforcing more competition for suppliers and better service to customers. Within the same lines, more focus on clusters of industries where companies will 
compete and learn from each other may significantly improve the economic development in a longer prospective and grow.

An important finding for policy also comes from the type of economic activity that matters for growth. The effect of financial intermediation and business services is the highest followed by mining, manufacturing and energy and finally agriculture in smaller cities. Our findings do not support previous findings that services have greater impacts on growth (Acs and Armington 2004; van Stel and Suddle 2008). This is not surprising, because large European cities, including capitals, have ports - e.g, Stockholm, Barcelona, Helsinki, Athena, Riga, Copenhagen, London, Lisbon. Also relevant for policy is the highest rates of economic development in established capitals - EU-15 capitals which have received most of economic development overtime. Targeting unemployment both in large and small market size cities should remain the priority for economic growth.

\section{CONCLUSIONS}

Large literature on regional economics and entrepreneurship addresses economic development as a determinant and as an outcome of entrepreneurship at different levels of analysis (Szerb et al. 2013; Fritsch and Schindele 2011; Dijkstra, Garcilazo and McCann 2013; Glaeser et. al., 2014). Although the recent research has identified notable regional differences in these effects and between high and low-density areas and the role of agglomeration economies (Fritsch and Mueller 2004; Beaudry and Schiffauerova, 2009; de Groot, Poot and Smit, 2009;), the direct and indirect effect of new start-ups on economic development has not been addressed for cities with a different market size. We analysed the effects of new business formation on urban economic development measured with the GDP per capita in purchasing power parity. Our empirical results suggest that new business formation may significantly improve economic development with the direct effect being positive and statistically significant for cities with both small, medium and large market sizes. These direct effects show a considerable dynamic and magnitude overtime between smaller and larger economies. The indirect effects are positive for large cities only and the effect does not occur in small and mediumsize cities. More specifically it takes up to three years the displacement effect for large cities and up to seven years for small cities.

Our findings provide new evidence for regional economic literature with a new firm formation in focus. Firstly, we support the effectiveness of entrepreneurial start-ups to achieve higher economic development in cities with a higher market size (Glaeser et al. 1992, 1995; Acs et al. 2008b); Secondly, the new business start-up immediate growth impact is positive and statistically significant for both large and small size markets (Fritsch and Noseleit 2013); Thirdly, the indirect affects needs 
critical mass to mature and grow with the effect being positive in a seven year time. It is unlikely to happen in smaller and medium size market (Fritsch and Mueller 2004; Andersson and Koster 2011).

The critical argument here is that new entries in the large agglomeration economies make critical improvements to competition and quality, with incumbents leaving the market. This results in a U-shaped relationship where direct, displacement and stronger supply-side or spillover effects are observed (Fritsch and Noseleit 2013). Non-competitive new firms and incumbents exit the market, through the creative destruction mechanism (Schumpeter 1939) while the more competitive businesses remains. This results in higher productivity, greater information exchange, and further knowledge spillovers.

The supply-side effect (indirect effects) never appears in a small and medium market size ( $<250,000$ inhabitants). The magnitude of the effect may vary according to the characteristics of the entrants and industry (Andersson et al 2011). For instance, more high-tech start-ups will offer greater challenges to incumbents than necessity-driven start-ups, which remain a a direction for further research.

Future research is needed to better understand how the structure of a market and larger time lag effects are linked with entrepreneurship and economic development, contrasting different levels of agglomeration. For example, the extent to which market saturation exists in a city could determine how, and for how long entrepreneurship may contribute to economic development with the displacement affect taking longer time. This could shed more light on Schumpeterian's (1934) theories that suggest entrepreneurship is paramount in transforming economies and boosting growth. In addition, future research could consider how the impact of time might vary in industries with significant capital requirements, where entry barriers could be higher and it may take firms longer to start making profits.

\section{Endnotes}

1. Acs and Armington 2004; Carree and Thurik 2008.

2. Florida et al. 2008; Acs et al. 2009; Rodriguez-Pose and Crescenzi, 2008.

3. The UAS data were obtained from the Eurostat New Cronos dataset, available from http://www.esds.ac.uk.

4. A regional capital is the main city of a region, such as Leicester (the main city of Leicestershire), York (the main city of Yorkshire), and Palermo (the main city of Sicily). For more, see Eurostat 2011.

5. Some studies exclude companies below a size threshold, e.g., 10 employees (see Fritsch and Mueller 2004). 
6. Re-invented capitals - champions of transition, engines of economic activity for the New Member States, usually capital cities; Established capitals - firmly positioned at the top of national urban hierarchies, with a diversified economic base and concentrations of wealth (European Commission, 2007).

7. If standardized by national average, this measure would be essentially the same as the measure in Glaeser et al. (1992).

8. We appreciate one of the referee's suggestion on this.

\section{ACKNOWLEDGEMENTS}

We thank Rolf Sternberg, Taylor Aldridge, Stepan Zemtsov, Frank van Oort, Christoph Alfken, Johan Klaesson, Mikaela Backman and participants in the "Geography of Innovation and Growth" session at the $17^{\text {th }}$ Uddevalla Symposium in Uddevalla, Sweden (June, 12-14, 2014).

\section{REFERENCES}

Acs ZJ, Armington C (2004) The impact of geographic differences in human capital on service firm formation rates," Journal of Urban Economics, 56(2): 244-278.

Acs ZJ, Desai S, Klapper L (2008a) What does "entrepreneurship data really show? Small Business Economics 31: 265-281.

Acs ZJ, Desai S, Hessels J (2008b) Entrepreneurship, Economic Development and Institutions. Small Business Economics 31: 219-234.

Acs ZJ, Braunerhjelm, P, Audretsch D, Carlsson B (2009) The knowledge spillover theory of entrepreneurship. Small business economics 32: 15-30.

Acs ZJ, Autio E, Szerb L (2014) National Systems of Entrepreneurship: Measurement Issues and Policy Implications. Research Policy 43: 476-449.

Aiginger K (2006) Revisiting an Evasive Concept: Introduction to the Special Issue on Competitiveness. Journal of Industry, Competition and Trade 6(2): 63-66.

Andersson M, Noseleit F (2011) Start-ups and employment growth-evidence from Sweden. Small Business Economics 36: 461-483.

Andersson M, Koster S (2011) Sources of persistence in regional start-up rates-evidence from Sweden. Journal of Economic Geography 11: 179-201.

Andersson M, Braunerhjelm P, Thulin P (2011) Creative Destruction and Productivity entrepreneurship by type, sector and sequence. Working Paper Series in Economics and Institutions of Innovation 256, Royal Institute of Technology, CESIS.

Arellano M, Bond S (1991) Some tests of specification for panel data: Monte Carlo evidence and an application to employment equations. Review of Economic Studies 58: 277-297.

Audretsch DB. (1995). Innovation and Industry Evolution. MIT Press, Cambridge.

Audretsch DB (2003). Entrepreneurship: A Survey of the Literature. Enterprise Paper Number 14. Enterprise Directorate-General, Brussels.

Audretsch DB, Belitski M (2013) The missing pillar: the creativity theory of knowledge spillover entrepreneurship. Small Business Economics 41: 819-836.

Baltagi B. (2008). Econometric analysis of panel data. John Wiley \& Sons.

Baptista R, Preto MT. (2011). New firm formation and employment growth: regional and business dynamics. Small Business Economics 36: 419-442

Beaudry C, Schiffauerova A (2009) Who's Right, Marshall or Jacobs? The Localization

versus Urbanization Debate. Research Policy 38(2): 318-337. 
Belitski M, Korosteleva J (2011) Entrepreneurship and cities: Evidence from the Post-Communist world. Frontiers of Entrepreneurship Research 31.

Bosma N, Sternberg R (2014) Entrepreneurship as an urban event? Empirical evidence from European cities. Regional Studies 48: 1016-1033.

Brakman S, Garretsen H, Van Marrewijk C (2009) Economic geography within and between European nations: The role of market potential and density across space and time. Journal of Regional Science 49: 777-800.

Capello R, Camagni R. P, Chizzolini B, Fratesi U (2008). Modelling regional scenarios for the enlarged Europe: European competitiveness and global strategies. Springer Science and Business Media.

Carree MA, Thurik R (2008) The lag structure of the impact of business ownership on economic performance in OECD countries. Small Business Economics 30: 101-110.

Cheshire P, Magrini S. (2009) Urban growth drivers in a Europe of sticky people and implicit boundaries. Journal of Economic Geography 9: 85-115.

Chinitz B.J (1961) Contrasts in agglomeration: New York and Pittsburgh. American Economic Review 51: 279-289.

Crescenzi R, Rodriguez-Pose A, Storper M (2007) The Territorial Dynamics of Innovation: A Europe-United States Comparative Analysis. Journal of Economic Geography 7: 673-709.

De Groot HL, Poot J, Smit MJ (2009) Agglomeration, Innovation and Regional

Development: Theoretical Perspectives and Meta-Analysis. In: Capello R. and Nijkamp

P. (ed). Handbook of regional growth and development theories. Edward Elgar,

Cheltenham, pp. 256-281.

Dejardin M (2011) Linking net entry to regional economic growth. Small Business Economics 36: 443-460.

Dijkstra L, Garcilazo E, McCann P (2013) The economic performance of European cities and city regions:

Myths and realities. European Planning Studies 21(3): 334-354.

Dijkstra, L., \& Poelman, H. (2012). Cities in Europe: The New OECD-EC Definition. Regional Focus, 1, 2012.

Available at http://ec.europa.eu/regional policy/sources/docgener/focus/2012 01 city.pdf

Department of Trade and Industry (1998) Regional Competitiveness Indicators. London: HMSO.

Douglas PH (1976) The Cobb-Douglas production function once again: its history, its testing, and some new empirical values. Journal of Political Economy 84: 903-915.

Estrin S, Korosteleva J, Mickiewicz T (2013) Which institutions encourage entrepreneurial growth aspirations? Journal of business venturing 28: 564-580.

European Commission. 2007. The second State of European cities report. Accessed 26 october 2014 http://ec.europa.eu/regional_policy/sources/docgener/studies/pdf/urban/stateofcities_2010.pdf

\begin{tabular}{lllllll}
\hline Eurostat. 2011. Regional and urban statistics. Accessed 26 & october 2014
\end{tabular} http://epp.eurostat.ec.europa.eu/portal/page/portal/region_cities/city_urban

Faggian, A, McCann P (2009) Human Capital, Graduate Migration and Innovation in British Regions. Cambridge Journal of Economics 33: 317-333.

Florida R (2002) The rise of the creative class: and how it's transforming work, leisure, community and everyday life. New York Basics, New York.

Florida R, Mellander C, Stolarick K (2008) Inside the black box of regional development - human capital, the creative class and tolerance. Journal of economic geography 8: 615-649.

Fritsch M, Mueller P. (2004) Effects of New Business Formation on Regional Development over Time. Regional Studies 38: 961-975

Fritsch M, Mueller P. (2008) The effect of new business formation on regional development over time: the case of Germany, Small Business Economics 30: 15-29

Fritsch M, Schindele Y (2011) The contribution of new businesses to regional employmentan empirical analysis. Economic Geography 87: 153-170 
Fritsch M, Noseleit F (2013) Investigating the anatomy of the employment effect of new business formation. Cambridge journal of economics 37: 349-377.

Fritsch M, Storey D (2014) Entrepreneurship in a Regional Context: Historical Roots, Recent Developments and Future Challenges. Regional Studies 48: 939-954.

Fritsch M, Wyrwich M. (2014a) The Long Persistence of Regional Levels of Entrepreneurship: Germany 1925 to 2005. Regional Studies 48: 955-973.

Fritsch M, Wyrwich M. (2014b) The Effect of Regional Entrepreneurship Culture on Economic Development-Evidence for Germany. Jena Economic Research Papers 014.

Glaeser EL, Kallal H, Sheinkman J, Schleifer, A. (1992) Growth in Cities. Journal of Political Economy 100: 1126-1152.

Glaeser EL, Sheinkman J, Schleifer A (1995) Economic development in a Cross-Section of Cities. Journal of Monetary Economics 35: 117-143.

Glaeser EL, Kerr WR, Ponzetto G (2010) Clusters of entrepreneurship. Journal of Urban Economics 67: 150-168.

Glaeser EL, Ponzetto G, Tobio K (2014) Cities, Skills and Regional Change. Regional Studies 48: 7 43.

Hausman N (2012): University Innovation, Local Economic Growth, and Entrepreneurship. US Census Bureau Center for Economic Studies Paper No. CES-WP-12-10.

Jacobs J (1969) The Economies of Cities. Random House, New York.

Klepper S (1997) Industry life cycles. Industrial and Corporate Change 6: 145-181.

Marshall A (1890) Principles of Economics. MacMillan, London.

Mueller P, van Stel A, Storey DJ (2008) The Effects of New Firm Formation on Regional Development Over Time: The Case of Great Britain. Small Business Economics 30: 59-71.

OECD (2012) Redefining Urban: a new way to measure metropolitan areas. Available at

http://www.oecd.org/regional/redefiningurbananewwaytomeasuremetropolitanareas.htm

Accessed 12 April 2015.

Rosenthal SS, Strange WC (2004) Evidence on the Nature and Sources of Agglomeration Economies. In: Henderson V. and Thisse JF. (ed). Handbook of Regional and Urban

Economics. Elsevier, Amsterdam, pp. 2119-2171.

Rodriguez-Pose A, Crescenzi R (2008) Research and Development, Spillovers, Innovation Systems, and the Genesis of Regional Growth in Europe. Regional Studies 42: 51-67.

Saxenian A (1994) Regional Advantage: Culture and Competition in Silicon Valley and Route 128. Harvard University, Cambridge.

Szerb L, Acs Z, Autio E, Ortega-Argiles R, Komlosi E. (2013). REDI: The Regional Entrepreneurship and Development Index - Measuring regional entrepreneurship.. Final Report. $\begin{array}{llll}\text { Accessed } & 26 & \text { october } & \end{array}$ http://ec.europa.eu/regional_policy/sources/docgener/studies/pdf/regional_entrepreneurship_develop ment_index.pdf

Schwab K (2010) The global competitiveness report 2010-2011. Geneva.

Schumpeter J.A (1934) The Theory of Economic Development: An Inquiry into Pro- fits, Capital, Credit al.t, Interest, and the Business Cycle. Harvard University Press, Cambridge.

Schumpeter J.A (1949) Economic theory and entrepreneurial history-Change and the entrepreneur; postulates and patterns for entrepreneurial history. Harvard University Press, Cambridge.

Shane S, Venkataraman S (2000). The promise of entrepreneurship as a field of research. Academy of Management Review 25: 217-226.

Stam E (2014). The Dutch entrepreneurial ecosystem. Accessed 15 October 2014. http://papers.ssrn.com/sol3/papers.cfm?abstract_id=2473475

Van Stel A, Carree M, Thurik R (2005) The effect of entrepreneurial activity on national economic development. Small business economics 24: 311-321. 
van Stel, A, Suddle K (2008) The impact of new firm formation on regional development in the Netherlands. Small Business Economics 30: 31-47. 
Table 1: Descriptive statistics and definitions of the variables

\begin{tabular}{|c|c|c|c|c|}
\hline Variable & Definition & Obs. & Mean & St. dev. \\
\hline GDP pc & GDP per capita in PPP prices, logarithm & 319 & 10.00 & 0.51 \\
\hline Unemployment & Unemployment rate - \% & 319 & 10.69 & 5.13 \\
\hline New business & $\begin{array}{c}\text { New businesses registered in proportion of } \\
\text { existing companies }\end{array}$ & 319 & 19.16 & 12.87 \\
\hline New business L.1 & First lag of prop. of new businesses registered & 319 & 22.01 & 14.76 \\
\hline New business L.2 & First lag of prop. of new businesses registered & 319 & 24.50 & 17.33 \\
\hline $\begin{array}{c}\text { Education medium } \\
\text { (3-4 ISCED) }\end{array}$ & $\begin{array}{l}\text { Proportion of residents with basic education } \\
\text { (High school degrees) }\end{array}$ & 319 & 22.57 & 7.57 \\
\hline $\begin{array}{l}\text { Education high (5-6 } \\
\text { ISCED) }\end{array}$ & $\begin{array}{l}\text { Proportion of residents with high education } \\
\text { (University and college degrees) }\end{array}$ & 319 & 44.37 & 12.65 \\
\hline EU & $\begin{array}{c}\text { Dummy variable }=1 \text { if city is in the EU, zero } \\
\text { otherwise }\end{array}$ & 319 & 0.85 & 0.36 \\
\hline $\begin{array}{c}\text { Business } \\
\text { specialization: A }\end{array}$ & $\begin{array}{l}\text { Business specialization: number of employed in } \\
\text { NACE A /population*1000 }\end{array}$ & 319 & 5.02 & 9.46 \\
\hline $\begin{array}{c}\text { Business } \\
\text { specialization: B-E }\end{array}$ & $\begin{array}{l}\text { Business specialization: number of employed in } \\
\text { NACE B-E /population*1000 }\end{array}$ & 319 & 84.61 & 38.14 \\
\hline $\begin{array}{c}\text { Business } \\
\text { specialization: } \mathrm{J}-\mathrm{K} \\
\end{array}$ & $\begin{array}{l}\text { Business specialization: number of employed in } \\
\text { NACE J-K /population*1000 }\end{array}$ & 319 & 103.35 & 30.81 \\
\hline $\begin{array}{c}\text { Business } \\
\text { specialization: G-I }\end{array}$ & $\begin{array}{l}\text { Business specialization: number of employed in } \\
\text { NACE G-I /population*1000 }\end{array}$ & 319 & 105.02 & 70.48 \\
\hline $\begin{array}{c}\text { Business } \\
\text { specialization: L-P }\end{array}$ & $\begin{array}{l}\text { Business specialization: number of employed in } \\
\text { NACE L-P /population* } 1000\end{array}$ & 319 & 186.69 & 61.55 \\
\hline GCI High & $\begin{array}{l}\text { Dummy variable }=1 \text { if country is Top } 20 \text { by The } \\
\text { Global Competitiveness Index }(2007-2008)\end{array}$ & 319 & 0.73 & 0.44 \\
\hline GCI Medium & $\begin{array}{l}\text { Dummy variable }=1 \text { if country is Top } 50 \text { by The } \\
\text { Global Competitiveness Index }(2007-2008)\end{array}$ & 319 & 0.18 & 0.38 \\
\hline GCI Low & $\begin{array}{l}\text { Dummy variable }=1 \text { if country below Top } 50 \text { by } \\
\text { The Global Competitiveness Index (2007-2008) }\end{array}$ & 319 & 0.09 & 0.29 \\
\hline & Knowledge hub & 319 & 0.16 & 0.37 \\
\hline & De-industrialised cities & 319 & 0.06 & 0.24 \\
\hline & Gateways & 319 & 0.03 & 0.17 \\
\hline & Regional market centres & 319 & 0.10 & 0.31 \\
\hline & Research centres & 319 & 0.08 & 0.28 \\
\hline & Modern industrial centres & 319 & 0.09 & 0.29 \\
\hline & Re-invented capitals & 319 & 0.03 & 0.18 \\
\hline & egional public service centres & 319 & 0.07 & 0.26 \\
\hline & Satellite towns & 319 & 0.02 & 0.15 \\
\hline & Visitor centres & 319 & 0.06 & 0.23 \\
\hline & Established capitals & 319 & 0.02 & 0.15 \\
\hline & National service hubs & 319 & 0.06 & 0.24 \\
\hline & Transformation poles & 319 & 0.20 & 0.40 \\
\hline
\end{tabular}

Source: Urban Audit Survey 1993-2009 Eurostat (2011) World Economic Forum The Global Competitiveness Report (2009) Accessed 1 september 2014. http://www.weforum.org .

Note: Although all variables are included in the regression, a subset of city-type was supressed to safe space. Estimate coefficients are available from authors on request 
Table 2: Correlation matrix*

\begin{tabular}{|c|c|c|c|c|c|c|c|c|c|c|c|c|c|c|c|c|c|}
\hline & $\begin{array}{l}: \\
\text { : } \\
\text { Оิ }\end{array}$ & 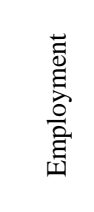 & 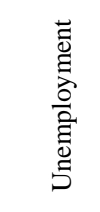 & 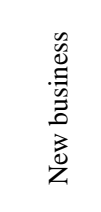 & $\begin{array}{l}\vec{J} \\
0 \\
0 \\
.0 \\
0 \\
0 \\
z \\
z \\
z \\
z\end{array}$ & 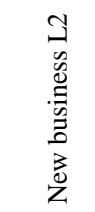 & 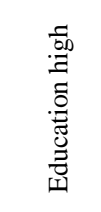 & 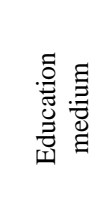 & 贫 & 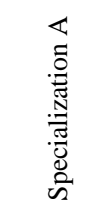 & 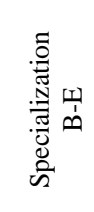 & 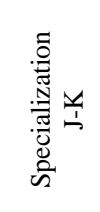 & 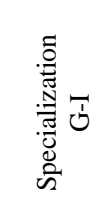 & 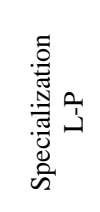 & 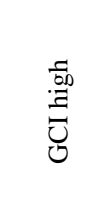 & 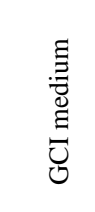 & 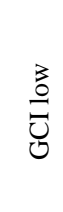 \\
\hline GDP pc & 1 & & & & & & & & & & & & & & & & \\
\hline Employment & $0.34 *$ & 1 & & & & & & & & & & & & & & & \\
\hline Unemployment & $-0.52 * *$ & -0.74 & 1 & & & & & & & & & & & & & & \\
\hline New business & $0.42 *$ & $0.16^{*}$ & 0.01 & 1 & & & & & & & & & & & & & \\
\hline New business L1 & 0.06 & $0.14^{*}$ & $0.34 *$ & $0.52 *$ & 1 & & & & & & & & & & & & \\
\hline New business L2 & -0.05 & $0.16^{*}$ & $0.65^{*}$ & $0.35^{*}$ & $0.57^{*}$ & 1 & & & & & & & & & & & \\
\hline Education high & $0.26^{*}$ & $0.26^{*}$ & 0.00 & -0.01 & $0.15^{*}$ & $0.24 *$ & 1 & & & & & & & & & & \\
\hline Education medium & $-0.35^{*}$ & 0.05 & $0.55^{*}$ & $0.18^{*}$ & $0.40^{*}$ & $0.57^{*}$ & 0.06 & 1 & & & & & & & & & \\
\hline $\mathrm{EU}$ & $0.67 *$ & $0.10^{*}$ & $-0.46^{*}$ & $0.32 *$ & $-0.16^{*}$ & $-0.49^{*}$ & $0.16^{*}$ & $-0.49^{*}$ & 1 & & & & & & & & \\
\hline Specialization A & -0.03 & $-0.09 *$ & $\begin{array}{l}-0.05 \\
\end{array}$ & -0.03 & $\begin{array}{l}-0.09 \\
\end{array}$ & -0.09 & -0.03 & -0.06 & 0.05 & 1 & & & & & & & \\
\hline Specialization B-E & -0.04 & $0.21 *$ & $-0.09^{*}$ & 0.00 & 0.02 & 0.04 & $-0.18 *$ & $0.27 *$ & $-0.13^{*}$ & $0.15^{*}$ & 1 & & & & & & \\
\hline Specialization J-K & $0.51^{*}$ & -0.01 & $-0.61 *$ & $0.13^{*}$ & $-0.18^{*}$ & $-0.35^{*}$ & -0.08 & $-0.42^{*}$ & $0.35^{*}$ & 0.05 & $0.27 *$ & 1 & & & & & \\
\hline Specialization G-I & $0.68 *$ & $0.19^{*}$ & $-0.38^{*}$ & $0.27 *$ & 0.11 & -0.01 & $0.28 *$ & $-0.23 *$ & $0.32 *$ & $-0.09 *$ & -0.02 & $0.57 *$ & 1 & & & & \\
\hline Specialization L-P & $0.52 *$ & $0.17^{*}$ & $-0.33^{*}$ & $0.23^{*}$ & 0.01 & -0.04 & $0.29 *$ & $-0.26^{*}$ & $0.45^{*}$ & -0.04 & -0.08 & $0.48^{*}$ & $0.51 *$ & 1 & & & \\
\hline GCI high & $0.66^{*}$ & $0.15^{*}$ & $-0.30^{*}$ & $0.44 *$ & $0.18^{*}$ & 0.04 & $0.19^{*}$ & $-0.26^{*}$ & $0.69^{*}$ & $-0.14 *$ & $-0.20 *$ & $0.16^{*}$ & $0.32 *$ & $0.45^{*}$ & 1.00 & & \\
\hline GCI medium & $-0.37 *$ & $-0.15^{*}$ & 0.00 & $-0.33^{*}$ & $-0.16^{*}$ & -0.04 & -0.07 & 0.00 & $-0.22 *$ & $0.23^{*}$ & $0.24 *$ & $0.18^{*}$ & $-0.16^{*}$ & $-0.21 *$ & $-0.75^{*}$ & 1 & \\
\hline GCI low & $-0.52 *$ & -0.03 & $0.47 *$ & $-0.24 *$ & -0.08 & - & $-0.20 *$ & $0.40^{*}$ & $-0.76^{*}$ & -0.09 & -0.01 & $-0.49 *$ & $-0.28^{*}$ & $-0.41 *$ & $-0.53 *$ & $-0.14^{*}$ & 1 \\
\hline
\end{tabular}

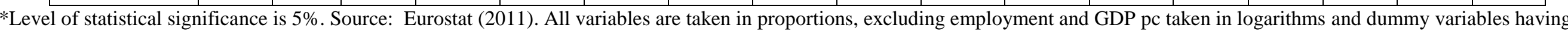
binary values. 
Table 3: Entrepreneurship and economic development model: Random effects estimation*

\begin{tabular}{|c|c|c|c|c|c|c|}
\hline \multirow[b]{2}{*}{ Model specification } & \multicolumn{3}{|c|}{ Small and medium-sized cities $<250,000$ residents } & \multicolumn{3}{|c|}{ Large cities $>250,000$ residents } \\
\hline & (1) & (2) & (3) & (4) & (5) & (6) \\
\hline Unemployment & $\begin{array}{l}-0.022 \\
(0.03) \\
\end{array}$ & $\begin{array}{c}-0.027 * * * \\
(0.01)\end{array}$ & $\begin{array}{l}-0.001 \\
(0.01) \\
\end{array}$ & $\begin{array}{c}-0.026 * * * \\
(0.01) \\
\end{array}$ & $\begin{array}{c}-0.043 * * * \\
(0.01) \\
\end{array}$ & $\begin{array}{c}-0.062 * * * \\
(0.02)\end{array}$ \\
\hline New business & $\begin{array}{c}0.0047 * * \\
(0.00)\end{array}$ & & & $\begin{array}{c}0.0037 * * \\
(0.00)\end{array}$ & & \\
\hline New business L.1 & & $\begin{array}{c}0.0041 * * \\
(0.00)\end{array}$ & & & $\begin{array}{c}0.0010 \\
(0.00)\end{array}$ & \\
\hline New business L.2 & & & $\begin{array}{c}-0.0009 \\
(0.00)\end{array}$ & & & $\begin{array}{c}0.0072 * * \\
(0.00)\end{array}$ \\
\hline $\begin{array}{l}\text { Education medium (3-4 } \\
\text { ISCED) }\end{array}$ & $\begin{array}{l}0.006 \\
(0.01)\end{array}$ & $\begin{array}{l}0.004 \\
(0.01)\end{array}$ & $\begin{array}{c}0.011 * * \\
(0.01)\end{array}$ & $\begin{array}{c}-0.011 * * * \\
(0.00)\end{array}$ & $\begin{array}{c}-0.009 * * * \\
(0.00)\end{array}$ & $\begin{array}{l}-0.004 \\
(0.00)\end{array}$ \\
\hline Education high (5-6 ISCED) & $\begin{array}{l}-0.001 \\
(0.01)\end{array}$ & $\begin{array}{l}-0.006 \\
(0.00)\end{array}$ & $\begin{array}{l}-0.002 \\
(0.00)\end{array}$ & $\begin{array}{l}-0.001 \\
(0.00)\end{array}$ & $\begin{array}{l}0.002 \\
(0.00)\end{array}$ & $\begin{array}{l}-0.002 \\
(0.00)\end{array}$ \\
\hline EU & $\begin{array}{l}0.045 \\
(0.13)\end{array}$ & $\begin{array}{r}-0.178 \\
(0.20)\end{array}$ & $\begin{array}{r}-0.040 \\
(0.06)\end{array}$ & $\begin{array}{l}0.056 \\
(0.06)\end{array}$ & $\begin{array}{l}0.013 \\
(0.09)\end{array}$ & $\begin{array}{l}0.288^{*} \\
(0.16)\end{array}$ \\
\hline Agriculture/fishery & $\begin{array}{l}0.005 \\
(0.00)\end{array}$ & $\begin{array}{c}0.011 * * * \\
(0.00)\end{array}$ & $\begin{array}{r}-0.002 \\
(0.01) \\
\end{array}$ & $\begin{array}{c}0.003 * * * \\
(0.00)\end{array}$ & $\begin{array}{l}0.006 \\
(0.01)\end{array}$ & $\begin{array}{c}0.003^{*} \\
(0.00)\end{array}$ \\
\hline Manufacturing, mining & $\begin{array}{c}0.002 * \\
(0.00)\end{array}$ & $\begin{array}{c}0.004 * * * \\
(0.00)\end{array}$ & $\begin{array}{c}0.003 * * * \\
(0.00)\end{array}$ & $\begin{array}{l}0.000 \\
(0.00) \\
\end{array}$ & $\begin{array}{l}0.000 \\
(0.00) \\
\end{array}$ & $\begin{array}{l}0.001 \\
(0.00) \\
\end{array}$ \\
\hline Retail & $\begin{array}{l}-0.001 \\
(0.00)\end{array}$ & $\begin{array}{c}-0.005^{* *} \\
(0.00)\end{array}$ & $\begin{array}{l}0.001 \\
(0.00)\end{array}$ & $\begin{array}{l}0.000 \\
(0.00)\end{array}$ & $\begin{array}{l}-0.001 \\
(0.00)\end{array}$ & $\begin{array}{c}-0.003 * * \\
(0.00)\end{array}$ \\
\hline Finance & $\begin{array}{c}0.003^{* * *} * \\
(0.00)\end{array}$ & $\begin{array}{c}0.002 * * * \\
(0.00)\end{array}$ & $\begin{array}{l}0.001 \\
(0.00)\end{array}$ & $\begin{array}{c}0.002^{* * *} \\
(0.00)\end{array}$ & $\begin{array}{c}0.002^{* * * *} \\
(0.00)\end{array}$ & $\begin{array}{c}0.003 * * * \\
(0.00)\end{array}$ \\
\hline Public & $\begin{array}{l}0.000 \\
(0.00)\end{array}$ & $\begin{array}{c}0.002 * * * \\
(0.00)\end{array}$ & $\begin{array}{l}0.000 \\
(0.00)\end{array}$ & $\begin{array}{l}0.000 \\
(0.00)\end{array}$ & $\begin{array}{l}0.000 \\
(0.00)\end{array}$ & $\begin{array}{l}0.001 \\
(0.00)\end{array}$ \\
\hline Knowledge hub & $\begin{array}{l}-0.076 \\
(0.20)\end{array}$ & $\begin{array}{c}-0.318^{*} \\
(0.16)\end{array}$ & $\begin{array}{l}0.155 \\
(0.18)\end{array}$ & $\begin{array}{c}0.295 * * * \\
(0.08)\end{array}$ & $\begin{array}{c}0.232 * * * \\
(0.07)\end{array}$ & $\begin{array}{l}0.124 \\
(0.12)\end{array}$ \\
\hline Research city & $\begin{array}{l}0.036 \\
(0.30) \\
\end{array}$ & $\begin{array}{r}-0.329 \\
(0.20) \\
\end{array}$ & $\begin{array}{r}-0.048 \\
(0.19) \\
\end{array}$ & $\begin{array}{c}0.213 * * \\
(0.10)\end{array}$ & $\begin{array}{c}0.192 * * \\
(0.09)\end{array}$ & $\begin{array}{l}0.071 \\
(0.12) \\
\end{array}$ \\
\hline Re-invented capitals & & & & $\begin{array}{l}0.144 \\
(0.10) \\
\end{array}$ & $\begin{array}{c}0.0637 \\
(0.12)\end{array}$ & $\begin{array}{l}0.209 \\
(0.16) \\
\end{array}$ \\
\hline Established capitals & & & & $\begin{array}{l}0.229 * \\
(0.14)\end{array}$ & $\begin{array}{l}0.207 * \\
(0.11)\end{array}$ & $\begin{array}{l}0.300^{*} \\
(0.16)\end{array}$ \\
\hline Constant & $\begin{array}{c}6.68 * * * \\
(1.30)\end{array}$ & $\begin{array}{c}5.83 * * * \\
(1.16) \\
\end{array}$ & $\begin{array}{c}7.90 * * * \\
(1.14) \\
\end{array}$ & $\begin{array}{c}10.02 * * * \\
(0.74) \\
\end{array}$ & $\begin{array}{c}9.75 * * * \\
(0.69)\end{array}$ & $\begin{array}{c}10.29 * * * \\
(1.04)\end{array}$ \\
\hline Year dummies & Yes & Yes & Yes & Yes & Yes & Yes \\
\hline GCI dummies & Yes & Yes & Yes & Yes & Yes & Yes \\
\hline F statistics & 18.39 & 13.04 & 11.91 & 33.01 & 28.06 & 14.33 \\
\hline Theta (50\% percentile) & 0.72 & 0.36 & 0.75 & 0.65 & 0.49 & 0.52 \\
\hline $\begin{array}{c}\text { F test that all city-type } \\
\text { dummies }=0\end{array}$ & 36.08 & 45.09 & 71.55 & 10.81 & 17.34 & 26.89 \\
\hline LR Test that all vi $=0\left(\chi^{2}\right)$ : & 23.48 & 15.29 & 9.62 & 51.96 & 83.06 & 12.36 \\
\hline
\end{tabular}

*Number of obs: 207 for large cities and 112 for small cities. Level of statistical significance is $* 0.1 \%$. $* * 0.05 \%$ and ***, $0.01 \%$. Excluded instrument: unemployment. Hausman test supports lagged moment condition for unemployment. Please see section 3.6. for more details. City type dummies are supressed to safe space, only those important in interpreting the research hypothesis are kept for demonstrative purposes (knowledge hub, Re-invented capitals, Research city and Established capital. F-test for all city dummies jointly $\gamma \mathrm{i}=0$ was rejected. We tested the presence of random effects in the model using Breusch and Pagan Lagrangian multiplier test for random effects $\operatorname{Var}(\gamma)=0$, and we rejected the null of city random effects to be not statistically significant (see test statistics reported beneath Table 3 ). The theta values vary between approx. 0.4-0.7 across different specification, indicating fixed effects preference.

Source: Authors calculation. 
Table 4: Entrepreneurship and economic development model: Pooled OLS robustness check

\begin{tabular}{|c|c|c|c|c|c|c|}
\hline \multirow{2}{*}{ Model specification } & \multicolumn{3}{|c|}{ Small and medium-sized cities $<250,000$ residents } & \multicolumn{3}{|c|}{ Large cities $>250,000$ residents } \\
\hline & (1) & (2) & (3) & (4) & (5) & (6) \\
\hline Unemployment & $\begin{array}{l}-0.026 \\
(0.03) \\
\end{array}$ & $\begin{array}{c}-0.031 * * * \\
(0.00) \\
\end{array}$ & $\begin{array}{c}-0.002 * \\
(0.00)\end{array}$ & $\begin{array}{c}-0.035 * * * \\
(0.01) \\
\end{array}$ & $\begin{array}{c}-0.050 * * * \\
(0.00)\end{array}$ & $\begin{array}{c}-0.075 * * * \\
(0.00)\end{array}$ \\
\hline New business & $\begin{array}{c}0.0051^{* *} \\
(0.00)\end{array}$ & & & $\begin{array}{c}0.0044 * * * \\
(0.00)\end{array}$ & & \\
\hline New business L.1 & & $\begin{array}{l}0.0053 * * * \\
(0.00)\end{array}$ & & & $\begin{array}{l}0.003 \\
(0.01)\end{array}$ & \\
\hline New business L.2 & & & $\begin{array}{l}-0.001 \\
(0.00)\end{array}$ & & & $\begin{array}{c}0.009 * * * \\
(0.00)\end{array}$ \\
\hline $\begin{array}{l}\text { Education medium (3-4 } \\
\text { ISCED) }\end{array}$ & $\begin{array}{l}0.007 \\
(0.01)\end{array}$ & $\begin{array}{l}0.005 \\
(0.00)\end{array}$ & $\begin{array}{c}0.013 * * \\
(0.02)\end{array}$ & $\begin{array}{c}-0.021 * * * \\
(0.00)\end{array}$ & $\begin{array}{c}-0.012 * * * * \\
(0.00)\end{array}$ & $\begin{array}{c}-0.009 * \\
(0.00)\end{array}$ \\
\hline Education high (5-6 ISCED) & $\begin{array}{l}-0.004 \\
(0.01)\end{array}$ & $\begin{array}{l}-0.009 \\
(0.00)\end{array}$ & $\begin{array}{l}-0.001 \\
(0.00)\end{array}$ & $\begin{array}{l}-0.003 \\
(0.00)\end{array}$ & $\begin{array}{l}0.002 \\
(0.00)\end{array}$ & $\begin{array}{l}-0.004 \\
(0.00)\end{array}$ \\
\hline EU & $\begin{array}{l}0.050 \\
(0.13)\end{array}$ & $\begin{array}{r}-0.199 \\
(0.30)\end{array}$ & $\begin{array}{r}-0.040 \\
(0.03)\end{array}$ & $\begin{array}{l}0.005 \\
(0.06)\end{array}$ & $\begin{array}{l}0.016 \\
(0.05)\end{array}$ & $\begin{array}{c}0.315^{* *} \\
(0.18)\end{array}$ \\
\hline Agriculture/fishery & $\begin{array}{l}0.007 \\
(0.00)\end{array}$ & $\begin{array}{c}0.013 * * \\
(0.00)\end{array}$ & $\begin{array}{l}-0.003 \\
(0.00) \\
\end{array}$ & $\begin{array}{c}0.002 * * \\
(0.00)\end{array}$ & $\begin{array}{c}0.002 * * \\
(0.00)\end{array}$ & $\begin{array}{c}0.003 * * \\
(0.00)\end{array}$ \\
\hline Manufacturing, mining & $\begin{array}{c}0.004 * * \\
(0.00)\end{array}$ & $\begin{array}{c}0.004 * * * \\
(0.00)\end{array}$ & $\begin{array}{c}0.005^{* *} * \\
(0.00)\end{array}$ & $\begin{array}{l}0.000 \\
(0.00)\end{array}$ & $\begin{array}{l}0.000 \\
(0.00)\end{array}$ & $\begin{array}{l}0.000 \\
(0.00)\end{array}$ \\
\hline Retail & $\begin{array}{r}-0.000 \\
(0.00) \\
\end{array}$ & $\begin{array}{l}-0.004 \\
(0.00) \\
\end{array}$ & $\begin{array}{l}0.000 \\
(0.00)\end{array}$ & $\begin{array}{l}0.001 \\
(0.00)\end{array}$ & $\begin{array}{l}0.001 \\
(0.00)\end{array}$ & $\begin{array}{l}0.002 * \\
(0.00)\end{array}$ \\
\hline Finance & $\begin{array}{c}0.002 * * \\
(0.00)\end{array}$ & $\begin{array}{c}0.003 * * * \\
(0.00)\end{array}$ & $\begin{array}{c}0.001 * * \\
(0.00)\end{array}$ & $\begin{array}{c}0.004 * * * \\
(0.00)\end{array}$ & $\begin{array}{c}0.004 * * \\
(0.00)\end{array}$ & $\begin{array}{c}0.004^{* *} \\
(0.00)\end{array}$ \\
\hline Public & $\begin{array}{l}0.001 \\
(0.00)\end{array}$ & $\begin{array}{c}0.001^{*} \\
(0.00)\end{array}$ & $\begin{array}{l}0.001 \\
(0.00)\end{array}$ & $\begin{array}{l}0.001 \\
(0.00)\end{array}$ & $\begin{array}{l}0.001 \\
(0.00)\end{array}$ & $\begin{array}{l}0.000 \\
(0.00)\end{array}$ \\
\hline Constant & $\begin{array}{c}7.54 * * * \\
(1.21) \\
\end{array}$ & $\begin{array}{c}5.89 * * * \\
(1.10)\end{array}$ & $\begin{array}{c}8.01 * * * \\
(1.54)\end{array}$ & $\begin{array}{c}12.22 * * * \\
(1.73) \\
\end{array}$ & $\begin{array}{c}11.55^{* * * *} * \\
(0.89)\end{array}$ & $\begin{array}{c}11.72 * * * \\
(0.98)\end{array}$ \\
\hline Year dummies & $\mathrm{NO}$ & $\mathrm{NO}$ & $\mathrm{NO}$ & $\mathrm{NO}$ & $\mathrm{NO}$ & $\mathrm{NO}$ \\
\hline GCI dummies & YES & YES & YES & YES & YES & YES \\
\hline F statistics & 14.41 & 11.15 & 10.01 & 28.04 & 20.08 & 13.23 \\
\hline
\end{tabular}

*Number of obs: 207 for large cities and 112 for small cities. Level of statistical significance is $* 0.1 \%$. $* * 0.05 \%$ and ***, $0.01 \%$. Excluded instrument: unemployment. City type dummies are not included in this model attempting to achieve maximum degrees of freedom. F-test for all city dummies jointly not significant $\gamma \mathrm{i}=0$ was not performed to safe degrees of freedom. Estimation method : Pooled OLS with standard errors robust for heteroskedasticity. Only 12 variables are included

Source: Authors calculation. 


\section{APPENDIX}

Figure 2: Average new firm start-up rates in European cities, 1994-2009

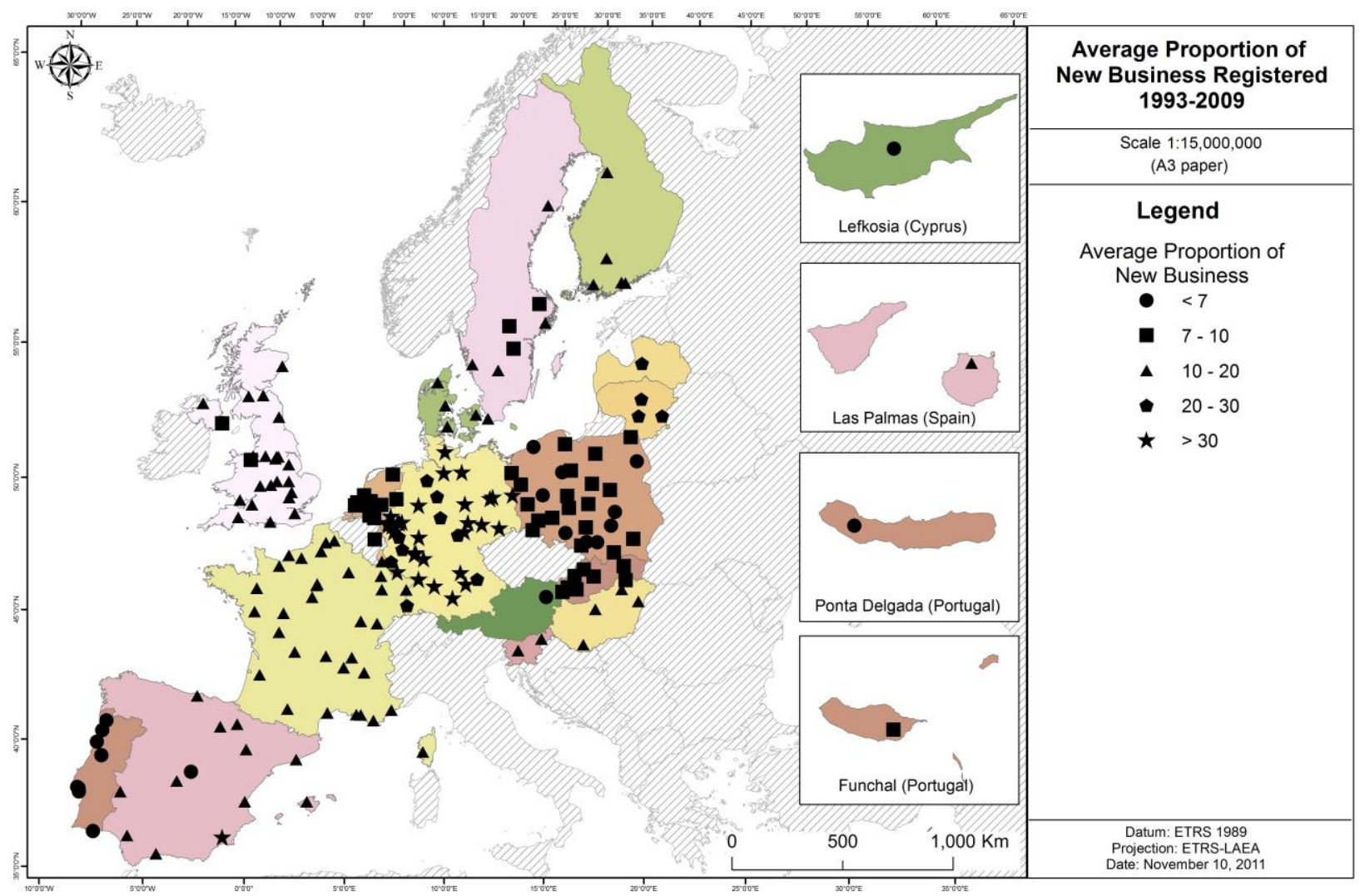

Source: Authors' calculations based on UAS data and the spatial information obtained from http://epp.eurostat.ec.europa.eu/portal/page/portal/gisco/popups/references/administrative_units_statistical_u nits_1. Note: the legend shows range bands of variation of the proportion of new businesses. 
Figure 3: Average GDP per capita in PPP in European cities, 1994-2009

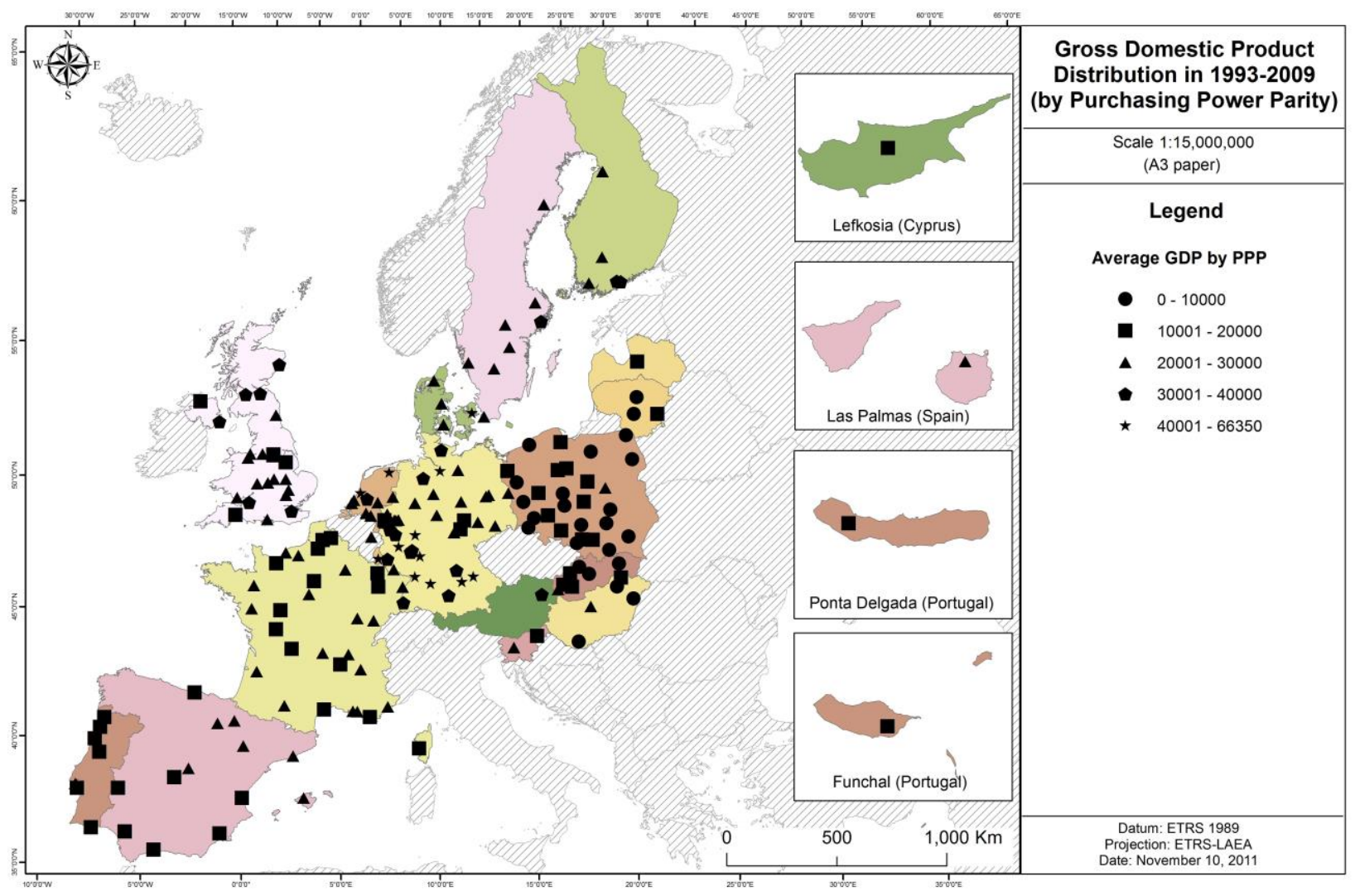

Source: Authors' calculations based on UAS data and the spatial information obtained from http://epp.eurostat.ec.europa.eu/portal/page/portal/gisco/popups/references/administrative_units_statistical_units_1. Note: the legend shows range bands of variation of the GDP per capita in PPP. 
Figure 1: The three effects of new business formation on employment change over time.

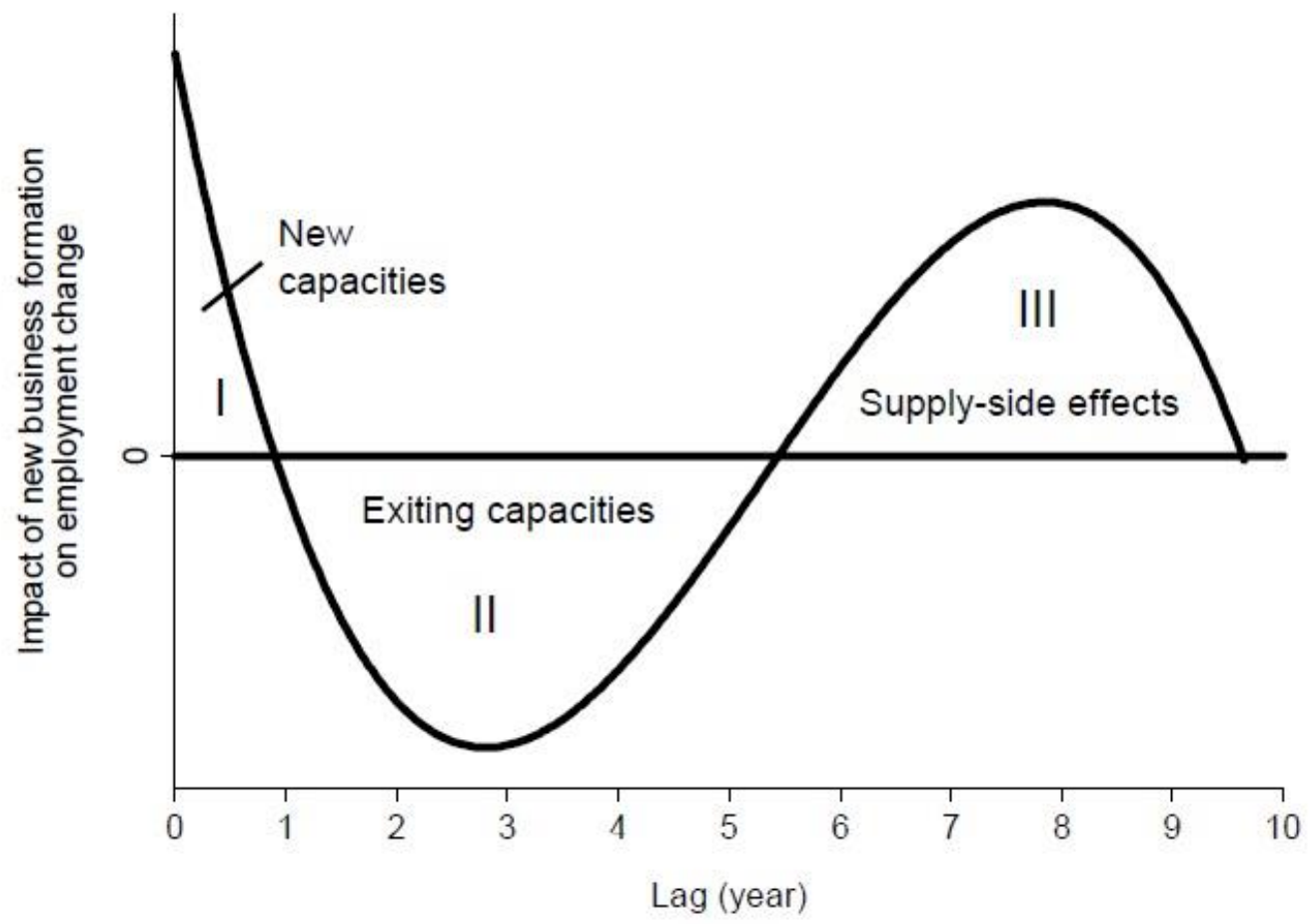

Source: Based on the results of Fritsch and Mueller, 2004, 2008 